\title{
Ceramiczne i szklane słoiki do przechowywania maści z badań archeologicznych w Gdańsku
}

\author{
Słowa kluczowe: maści, szkło, ceramika, archeologia, Gdańsk
}

Ceramiczne i szklane słoiki do przechowywania maści, pochodzące $\mathrm{z}$ badań archeologicznych w Gdańsku, nie stanowiły dotychczas przedmiotu szerszego opracowania naukowego - mimo umieszczania pojedynczych informacji o pojemnikach na leki w artykułach poświęconych odrębnym kategoriom przedmiotów ceramicznych i szklanych ${ }^{4}$.

${ }^{1}$ Instutu Archeologii i Etnologii, Uniwersytet Gdański, e-mail: joanna.dabal@ug.edu.pl, ORCID: 0000-0001-7325-2282.

2 Instytut Historii, Uniwersytet Gdański, e-mail: radek.kubus@gmail.com, ORCID: 0000-0002-3320-9308.

${ }^{3}$ Wojewódzki Urząd Ochrony Zabytków w Gdańsku, e-mail: karolina.szczepanowska@wp.pl, ORCID: 0000-0002-2112-8105.

${ }^{4}$ Egzemplarze opisane w większych zespołach z wykopalisk zob.: J. Dąbal, Hiszpańsko-mauretańskie naczynia ceramiczne, a status ekonomiczny ich posiadaczy i użytkowników. Nowe źródła z badań archeologicznych w Gdańsku, [w:] XVII Sesja Pomorzoznawcza, vol. 2: Od późnego średniowiecza do czasów nowożytnych, H. Paner, M. Fudziński (red.), Gdańsk 2013, s. 429-446; K. Szczepanowska, Wyroby Szklane, [w:] Gdańsk Twierdza Wisłoujście. Badania archeologiczno-architektoniczne w latach 2013-2014, J. Dąbal, K. Krawczyk, T. Widerski (red.), Gdańsk 2015, s. 299-324; M. Kasprzak, Ceramika naczyniowa z badań archeologicznych w Zespole Przedbramia ul. Długiej w Gdańsku, [w:] Zespót Przedbramia ul. Długiej w Gdańsku. Studium archeologiczne, A. Pudło (red.), Gdańsk 2016, s. 121-146; O. Krukowska, Przedmioty szklane z badan archeologicznych w Zespole Przedbramia ul. Długiej w Gdańsku, [w:] Zespót Przedbramia..., dz. cyt., s. 209-220. Większy zespół szklanych pojemników aptecznych zob.: O. Krukowska, Zespót naczyń szklanych z najnowszych badań Gdańska, [w:] Acta Archaeologica Pomoranica III. XVI sesja Pomorzoznawcza 22-24.11.2007 r. Szczecin. Część 2. Od późnego średniowiecza do czasów nowożytnych, A. Janowski, K. Kowalski, S. Słowiński (red.), Szczecin 2009, s. 247-256. 
Obszerniejsze badania podejmowane były w odniesieniu do innych stanowisk z terenu Polski ${ }^{5}$, niemniej nie obejmują one swoją tematyką ceramicznych naczyń aptecznych z okresu od XVI do XVIII w. Gdy porówna się obecny stan zaawansowania tych prac z problematyka podejmowaną na łamach literatury zagranicznej, studia archeologiczne związane $\mathrm{z}$ materialnymi aspektami historii medycyny i higieny w okresie nowożytnym możemy określić jako niezaawansowane ${ }^{6}$.

${ }^{5}$ S. Ciepiela, Szkło osiemnastowiecznej Starej Warszawy, Warszawa 1977; E. Cnotliwy, Szkło z XVI-XVIII wieku z Zamku Ksiażąt Pomorskich w Szczecinie, „Materiały Zachodniopomorskie” 1981, t. 27, s. 331-381; J. Olczak, Szklane naczynia apteczne z XVIII wieku odkryte w Brodnicy, „Acta Universitatis Nicolai Copernici”, Archeologia 1984, z. 10, s. 131-141; R. Kozłowska, A. Nowakowski, Szkło apteczne z badań archeologicznych Apteki Królewskiej w Warszawie, „Acta Universitatis Nicolai Copernici”, Archeologia 1987, z. 12, s. 123-141; M. Rubnikowicz, XVIII-wieczne naczynia szklane odkryte na Starym Mieście w Toruniu, „Acta Universitatis Nicolai Copernici”, Archeologia 1989, z. 14, s. 73-84; Ł. Brzeżycka, Późnośredniowieczne i nowożytne szklane naczynia apteczne odkryte na Starym Mieście w Poznaniu, „Acta Universitatis Nicolai Copernici”, Archeologia 1995, z. 22, s. 65-76; A. Magowska, E. Olkuska, Muzealia farmaceutyczne $w$ Poznaniu, „Nauka i praktyka farmaceutyczna w ochronie zdrowia: XVI Naukowy Zjazd, Warszawa, 20-21 października 1995: materiały zjazdowe”, bs.; A. Andrzejewska, Szkło naczyniowe z klasztoru OO. Dominikanów w Brześciu Kujawskim, województwo włocławskie, „Acta Universitatis Lodziensis. Folia Archaeologica 20" 1996, s. 123-153; J. Fonferek, Naczynia szklane z ulicy Stary Rynek 2-7 na Starym Mieście w Elblagu, [w:] XVII Sesja Pomorzoznawcza..., dz. cyt., s. 415-428; M. Nawracki, Późnośredniowieczne i nowożytne szkła z terenu Zamku Krzyżackiego w Toruniu, „Acta Universitatis Nicolai Copernici”, Archeologia 1999, z. 27, s. 53-132; K. Nowosielska, Średniowieczne i nowożytne wyroby szklane z badań na Starym Mieście we Wrocławiu, [w:] Wrocław na przełomie średniowiecza i czasów nowożytnych. Materialne przejawy życia codziennego, J. Piekalski, K. Wachowski (red.), Wrocław 2004, s. 57-88; E. Więcek, Butelki kamionkowe znalezione na terenie Apteki Królewskiej w Warszawie, „Kwartalnik Historii Kultury Materialnej” (dalej jako KwHKM) 2017, R. LXV, nr 3, s. 331-342.

${ }^{6}$ J. Baart, Zalfpotten XVI-XVIII, [w:] Opgrvingen in Amserdam, J. Baart (red.), Haarlem 1977, s. 276-283; H.J.E. van Beuningen, J. Hurst, D. Neal, Rotterdam Papers IV, Contribution to medieval archaeology. Pottery produced and traded in north-west Europe 1350-1650, Rotterdam 1986; H. Gangelen, J.J. Lenting, Ongeglazuurd aardewerk en loodglazuuraardewerk, [w:] Schans op de grens, J. Lenting, H. Gangelen, H. Westing (red.), Sellingen 1993, s. 167-236; H. Gangelen, J.J. Lenting, Steengoed, [w:] Schans op de grens..., dz. cyt., s. 309-333; E.M.Ch.F. Klijn, Loodglazuuraardewerk in Nederland. De collectie van het Nederlands Openluchtmuseum, Arnhem 1995; M. Bartels, Steden in Scherven 2. Catalogus. Vondsten uit beerputten in Deventer, Dordrecht, Nijmegen en Tiel (1250-1900), Amersfoort 1999; J. Cotter, Imported apothecary jars from Colchester, Essex, [w:] Maiolica in the North. The Archaeology of tin-glazed earthenware in NorthWest Europe c. 1500-1600, D. Gaimster (red.), London 1999, s. 167-170; Majolica and Glass. From Italy to Antwerp and Beyond. The transfer of technology in the 16th-early 17th century, J. Veeckman (red.), Antwerpen 2002; P. Steppuhn, Katalog, Vorbemerkung, [w:] Glaskultur in Niedersachsen. Tafelgeschirr und Haushaltsglas vom Mittelalter bis zur frühen Neuzeit. Archäologie undBauforschung in Lüneburg 5, E. Ring (red.), Husum 2003, s. 47-187; B. Hudson, English Delftware Drug Jars. The collection of the Museum of the Royal Pharmaceutical Society of Great Britain, London 2006; K. Tyler, I. Betts, R. Stephenson, London's delftware industry. The tin-glazed pottery industries 
Ceramiczne i szklane słoiki do przechowywania maści...

Celem niniejszego artykułu jest prezentacja słoików na maści $\mathrm{z}$ okresu od drugiej połowy XVI do XVIII w. pozyskanych w efekcie badań archeologicznych w wybranych obszarach Gdańska oraz próba uściślenia chronologii tych wyrobów. Zadanie to utrudnia niewielka liczba publikacji przedmiotów tej kategorii, ich niespójne opisy ${ }^{7}$ i dane liczbowe prezentowane w literaturze oraz szeroka chronologia przyjmowana dla opisywanych pojemników.

\section{Kontekst pozyskania źródeł}

Prezentowaną analizę materialnych świadectw użytkowania maści w Gdańsku oparto na wynikach badań archeologicznych na stanowiskach przy ul. Stara Stocznia/Wałowa 56 oraz 3 Maja 9 w Gdańsku (ryc. 1). W obu sytuacjach przedmioty zostały zdeponowane w miejscu odkrycia wtórnie. Uniemożliwia to interpretację wyrobów w kontekście konkretnych grup ekonomicznych czy zawodowych mieszkańców tych terenów.

\section{Stanowisko przy ul. Stara Stocznia/Wałowa $56^{8}$}

Stanowisko zlokalizowane jest w obrębie obszaru dawnej wyspy zagospodarowanej około połowy XVI w. przez cech wiadrowników9 ${ }^{9}$ Teren ten znajdował się $\mathrm{w}$ rejonie nieistniejących dzisiaj kanału Młyńskiego Raduni i kanału Eimermachergraben ${ }^{10}$. Istotne zmiany zagospodarowania przestrzeni miały miejsce w latach 30 . XVII w., kie-

of Southwark and Lambeth, London 2008; W. Endres, Ch. Habrich, G. Riedel, B. Schönewlad, Apothekengefäße von 1571 bis ins 18. Jahrhundert in Ingolstadt. Keramische und pharmaziehistorische Untersuchungen, Ingolstadt 2011; Amserdam Ceramics. A city history and archaeological ceramics catalogue 1175-2011, J. Gawronski (red.), Amsterdam 2011; K. Castillo Cardenas, Pharmaceutical glass in post-medieval London: a proposed typology, „London Archaeologist Winter” 2013/2014, s. 309-314.

7 Przykładowo, prace 0. Krukowskiej, gdzie autorka dokonuje literalnie identycznej interpretacji zawartej w akapicie dotyczącym słoików szklanych, nie podaje bliższych danych dotyczących kontekstu pozyskania, nie wskazuje różnic $w$ formach poszczególnych naczyń, stosuje szeroką chronologię określoną na XVI-XVII i XV-XIX w., jak również nie wskazuje, który przedział jest obowiązujący dla opisywanych materiałów. Zob.: O. Krukowska, Przedmioty szklane z badań..., dz. cyt., s. 248; tejże, Zespót naczyń szklanych..., dz. cyt., s. 216.

${ }^{8}$ Badania archeologiczne prowadziła w latach 2011-2012 firma Dart Jacek Gzowski. Kierownikiem badań terenowych był Patryk Muntowski, Muntowski P., 2012, Wyniki badań archeologicznych na stanowisku Wałowa / Stara Stocznia w Gdańsku. Gdańsk, woj. pomorskie, gm. Loco, ul. Stara Stocznia / Wałowa 56. Stanowisko nr 108, AZP 234, obszar 12-44. Działki 331/5, 331/7, 332/2, 333/3, 334, 335/6. Maszynopis w archiwum Pomorskiego Wojewódzkiego Konserwatora Zabytków.

${ }^{9}$ Z. Maciakowska, Studium historyczno-przestrzenne Wiadrowni, Gdańsk 2011, mps w archiwum Pomorskiego Wojewódzkiego Konserwatora Zabytków, s. 8.

${ }^{10}$ Tamże. 


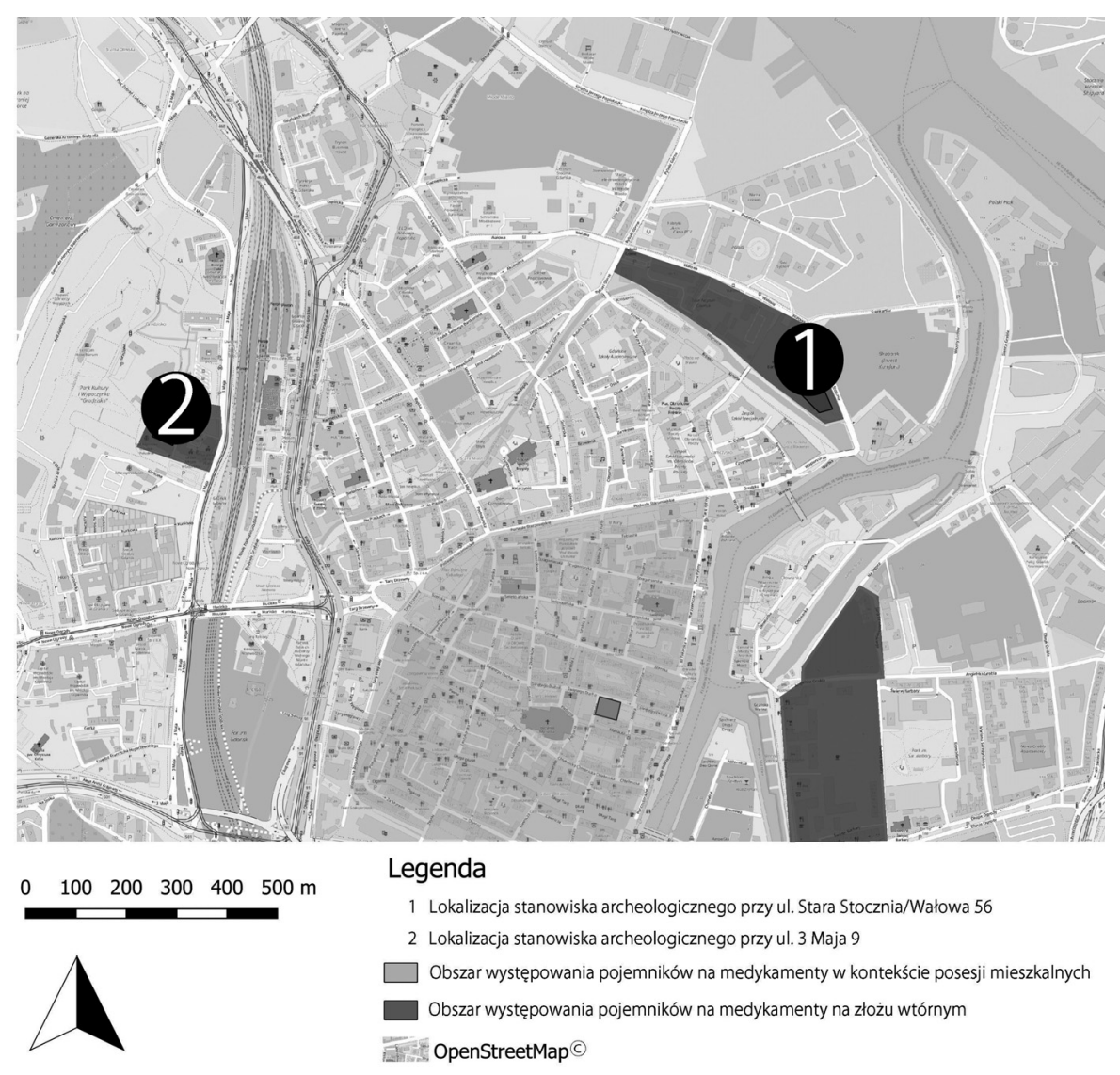

Ryc. 1. Gdańsk. Lokalizacja stanowisk archeologicznych, oprac. J. Dąbal.

dy w związku z rozbudową fortyfikacji miejskich zmieniono przebieg kanału Raduni, oraz od XVII do XIX w. w związku z intensyfikacją zabudowy na tym obszarze ${ }^{11}$. W trzeciej ćwierci XIX w. zasypano kanał Eimermachergraben, teren częściowo zniwelowano, modernizując zabudowę lub wznosząc nowe kamienice czynszowe podnajmowane przez mniej zamożnych Gdańszczan ${ }^{12}$.

W efekcie prac wykopaliskowych pozyskano osiem ceramicznych i szklanych słoików na maści. Prezentowane materiały wiążą się z XVII-wiecznymi przeobrażeniami terenu, na które składają się zasypanie części kanału Młyńskiego (warstwa 638) oraz niwelacja te-

11 Tamże, s. 12-36.

12 Tamże. 
renu (warstwa 797). Wyroby szklane i jeden egzemplarz ceramiczny pozyskano $\mathrm{z}$ warstw akumulacyjnych i zasypiskowych kanału Eimermachergraben datowanych od XVII do trzeciej ćwierci XIX w. (warstwy: 1805, 5333, 1807). Wyroby ceramiczne i szklane nie współwystępowały ze sobą w warstwach.

\section{Stanowisko przy ul. 3 Maja $9^{13}$}

Stanowisko zlokalizowane jest $\mathrm{w}$ obrębie północno-zachodniej linii nowożytnych fortyfikacji Gdańska, których budowę ukończono w $1655 \mathrm{r}$. W świetle dotychczasowych ustaleń od drugiej połowy XVII w. obszar został zajęty pod cmentarz, a następnie w XIX w. zabudowany po relokacji cmentarza. W wyniku eksploracji warstw związanych z budową nowożytnych fortyfikacji (warstwa 40) datowanych do lat 60. XVII w. pozyskano łącznie trzy fragmenty ceramicznych słoików na maści. Pozostałe dwa fragmenty słoika ceramicznego odsłonięto w warstwie niwelacyjnej datowanej na XIX w. (warstwa 60).

Tabela 1. Liczba analizowanych pojemników na maści z uwzględnieniem kontekstu pozyskania

\begin{tabular}{|l|l|c|c|}
\hline \multicolumn{1}{|c|}{$\begin{array}{c}\text { Stanowisko/jednostka } \\
\text { stratygraficzna }\end{array}$} & \multicolumn{1}{|c|}{$\begin{array}{c}\text { Nr } \\
\text { katalogowy }\end{array}$} & $\begin{array}{c}\text { Liczba } \\
\text { ceramicznych } \\
\text { fragmentów } \\
\text { pojemników }\end{array}$ & $\begin{array}{c}\text { Liczba } \\
\text { szklanych } \\
\text { fragmentów } \\
\text { pojemników }\end{array}$ \\
\hline $\begin{array}{l}\text { Stanowisko przy ul. 3 } \\
\text { Maja 9 (warstwa 40) }\end{array}$ & $\begin{array}{l}\text { C440, C470, } \\
\text { C471 }\end{array}$ & 3 & 0 \\
\hline $\begin{array}{l}\text { Stanowisko przy ul. 3 } \\
\text { Maja 9 (warstwa 60) }\end{array}$ & C480 & 2 & 0 \\
\hline $\begin{array}{l}\text { Stanowisko przy ul. Sta- } \\
\text { ra Stocznia/Wałowa 56 } \\
\text { (warstwa 638) }\end{array}$ & C2256 & & 0 \\
\hline $\begin{array}{l}\text { Stanowisko przy ul. Sta- } \\
\text { ra Stocznia/Wałowa 56 } \\
\text { (warstwa 797) }\end{array}$ & C2280 & 1 & 0 \\
\hline $\begin{array}{l}\text { Stanowisko przy ul. Sta- } \\
\text { ra Stocznia/Wałowa 56 } \\
\text { (warstwa 1805) }\end{array}$ & C902 & 1 & 0 \\
\hline
\end{tabular}

${ }^{13}$ Badania w latach 2009-2010 prowadziła firma Antiqua. Kierownikiem prac terenowych był Bogdan Bobowski. Por. B. Bobowski, P. Muntowski, Wstępne wyniki ratowniczych badań archeologicznych przy ul. 3 Maja 9 w Gdańsku na stanowisku nr 111, AZP 12-44, st. 230 w roku 2010, Gdańsk 2010, mps w archiwum Pomorskiego Wojewódzkiego Konserwatora Zabytków. 
Joanna Dąbal, Radosław Kubus, Karolina Szczepanowska

\begin{tabular}{|l|l|c|c|}
\hline $\begin{array}{l}\text { Stanowisko przy ul. Sta- } \\
\text { ra Stocznia/Wałowa 56 } \\
\text { (warstwa 1807) }\end{array}$ & SZ218, SZ456 & 0 & 4 \\
\hline $\begin{array}{l}\text { Stanowisko przy ul. Sta- } \\
\text { ra Stocznia/Wałowa 56 } \\
\text { (warstwa 5333) }\end{array}$ & SZ615 & & \\
\hline
\end{tabular}

\section{Pojemniki na maści}

Funkcja analizowanych wyrobów ceramicznych i szklanych definiowana jest w oparciu o formę ${ }^{14}$, skład zawartości ${ }^{15}$ oraz źródła ikonograficzne ${ }^{16}$. Prezentowane $\mathrm{w}$ artykule słoiki zidentyfikowano jako pojemniki do przechowywania maści. Pomocne w określaniu funkcji i chronologii prezentowanej kategorii wyrobów były opracowania źródłowe dotyczące warsztatów produkcyjnych, zespołów naczyń z aptek oraz znaleziska archeologiczne odkrywane na wrakach jednostek pływających, zdeponowane w kajutach lekarzy lub chirurgów okrętowych i w kontekście miejsc, w których funkcjonowały apteki. Uzupełnieniem tych danych są przytaczane źródła ikonograficzne przedstawiające zawody chirurgów, lekarzy czy szalbierzy. W jednym z analizowanych egzemplarzy zidentyfikowano substancję chemiczną ${ }^{17}$. $\mathrm{Z}$ obu opisanych stanowisk pozyskano łącznie 12 fragmentów słoików do przechowywania maści stanowiących pozostałość 11 pojemników.

Ze względu na pojemność podzielono je na trzy kategorie. Małe słoiczki o maksymalnej pojemności ok. $25 \mathrm{ml}$, w których wygodnie można było zdeponować maść o wadze wynoszącej $1 / 2$ uncji (15 gram), nieco większe słoiczki o maksymalnej pojemności od 47 do $95 \mathrm{ml}$, w których można było zdeponować maść o wadze wynoszącej od 1 do 3 uncji (90 gramów) oraz słoiki średniej wielkości o maksymalnej pojemności 420 do ok. $1300 \mathrm{ml}$, mieszczące maksymalnie ok. od 12 do 36 uncji specyfików. Do pierwszej kategorii należy 5 wyrobów zachowanych $\mathrm{w}$ całości, $\mathrm{z}$ niewielkimi ubytkami w wylewie lub zachowanych tylko w partii dna. Grupę tych pojemników reprezentują wyroby kamion-

${ }^{14}$ J. Baart, Zalfpotten XVI-XVIII, [w:] Opgrvingen in Amserdam, J. Baart (red.), Haarlem 1977, s. 276-283.

${ }_{15}$ A. Andrzejewska, dz. cyt., s. 123-153; por. J. Palmer, 'Patent medicines' study $\mathrm{X}$-rays old-time remedies, http://www.bbc.co.uk/news/science-environment-22065078 (dostęp: 27.01.2018); J. Fonferek, Elblag - everyday life in the Hanseatic port. Elblag życie codzienne w porcie hanzeatyckim, Elbląg 2012, s. 100-101.

${ }^{16} \mathrm{~J}$. Anderson, E. Barnes, E. Schackleton, The Art of Medicine: Over 2000 Years of Images and Imagination, Chicago 2011.

17 Egzemplarz o nr katalogowym C 440. 
kowe $^{18}$ i szklane ${ }^{19}$. Wyroby ceramiczne uformowane zostały na kole garncarskim z glin wypalonych na kolor ciemnoszary. Powierzchnie zewnętrzne pojemników pokryte są polewą żelazistą barwiącą się fioletowo-brązowo ${ }^{20}$ lub brązowo ${ }^{21}$. Dwa wyróżnione w tej kategorii kamionkowe słoiczki posiadają lekko gruszkowaty korpus z wyraźnym przewężeniem na wysokości szyjki. Jeden z pojemników posiada wylew o pogrubionej krawędzi rozchylony na zewnątrz (ryc. 2:1), otwór drugiego zakończony jest rozchylonym wylewem o krawędzi wywiniętej na zewnątrz (ryc. 2:2). Oba egzemplarze pozyskano $z$ warstw datowanych od pierwszej ćwierci do ok. połowy XVII w., niemniej jednak naczynko o żelazistej powierzchni datowane jest na drugą połowę XVI w., natomiast lekko smuklejszy pojemnik o brązowej powierzchni wytworzono $\mathrm{w}$ pierwszej połowie XVII w.22 Oba naczynka pochodzą z warsztatów niemieckich z rejonu Dolnej Saksonii ${ }^{23}$. W starszym słoiczku zachowała się zawartość (ryc. 2:1), substancję określono jako chemiczną ${ }^{24}$, jednak nie udało się jej zidentyfikować. Uzupełnieniem zespołu słoiczków tej kategorii są trzy wyroby szklane. Pierwszy z nich wykonano ze szkła bezbarwnego techniką dmuchania, o czym świadczą drobne bąbelki widoczne $\mathrm{w}$ masie słoika i ślady po przylepiaku

${ }_{18}$ Pierwszy pozyskany z badań przy ul. 3 Maja 9a, nr kat. C440; wymiary: średnica dna-24 mm, wysokość-39 mm, średnica wylewu-32,5 mm, pojemność - około $17 \mathrm{ml}$, objętość produktu w pojemniku $15 \mathrm{ml}, 1 / 2$ uncji, 15 gramów; drugi egzemplarz pozyskany podczas badań przy ul. Stara Stocznia/Wałowa 56, nr kat. C2256; wymiary: średnica dna - $24 \mathrm{~mm}$, wysokość - $38 \mathrm{~mm}$, średnica wylewu - $30 \mathrm{~mm}$, pojemność - około $17 \mathrm{ml}$, objętość produktu w pojemniku $15 \mathrm{ml}, 1 / 2$ uncji, 15 gramów.

${ }^{19}$ Szklane słoiczki pozyskane zostały podczas badań przy ul. Stara Stocznia/Wałowa 56, nr kat. SZ456; wymiary: średnica dna - $24 \mathrm{~mm}$, wysokość - $33 \mathrm{~mm}$, średnica wylewu - $30 \mathrm{~mm}$, pojemność - około $17 \mathrm{ml}$, objętość produktu w pojemniku $15 \mathrm{ml}, 1 / 2$ uncji, 15 gramów; nr kat. SZ218; wymiary: średnica dna - $28 \mathrm{~mm}$, wysokość - $42 \mathrm{~mm}$, średnica wylewu - $25 \mathrm{~mm}$, maksymalna objętość $25 \mathrm{ml}$, optymalna objętość produktu w pojemniku $15 \mathrm{ml}, 1 / 2$ uncji, 15 gramów; nr kat. SZ218; wymiary: średnica dna - $28 \mathrm{~mm}$, zachowana wysokość - $26 \mathrm{~mm}$.

${ }^{20} \mathrm{Nr}$ kat. C440.

${ }^{21}$ Nr kat. C2256.

${ }_{22}$ A. König, Weserware und Duinger Steinzeug in höxterschen Haushalten der Renaissance- and Barockzeit, [w:] Aus dem Pottland in die Welt. Eine historische Töpferregion zwischen Weser und Leine, G. Funke, Ch. Leiber (red.), Holzminden 2012, s. 144-145; H. Gangelen, J.J. Lenting, Steengoed, [w:] Schans op de grens..., dz. cyt., s. 328.

${ }^{23}$ Wykonano je prawdopodobnie w warsztatach w Duingen, zob.: A. König, dz. cyt., s. $144-145$.

${ }^{24}$ Badania zawartości nie dały jednoznacznych wyników: w skład substancji wchodził prawdopodobnie komponent organiczny, być może węglowodory aromatyczne oraz pierwiastki: tlenu, węgla, wapnia i molibdenu. Badania przeprowadziła dr inż. Aleksandra Mielewczyk-Gryń - Katedra Fizyki Ciała Stałego, Wydział Fizyki Technicznej i Matematyki Stosowanej, Politechnika Gdańska. 
na dnie (ryc. 2:3). Dno naczynia jest lekko wyniesione ${ }^{25}$, korpus ma kształt sakiewkowaty, a wylew słoiczka jest rozchylony na zewnątrz. Pojemnik w oparciu o cechy technologiczne i typologiczne datowano na drugą połowę XVIII w. Asortyment szklanych słoiczków uzupełniaja dwa analogicznie do siebie uformowane wyroby wykonane ze szkła barwionego, jasnozielonego, wykonane techniką dmuchania. Pojemniki wykonane zostały niestarannie, o czym świadczą nieregularne, różnych wielkości pęcherzyki powietrza rozmieszczone w masie szklanej oraz lekko asymetryczna forma (ryc. 2:4). Słoiczki posiadaja cylindryczny korpus, lekko wklęsły w środkowej partii. Dno pojemników jest lekko wyniesione ${ }^{26}$. Wylew wyrobów jest rozchylony na zewnątrz. Oba egzemplarze datowano na pierwszą ćwierć XVIII w. ${ }^{27}$ Wszystkie wymienione wyżej naczynia szklane pozyskane zostały $\mathrm{z}$ warstw akumulacyjnych kanału datowanych szeroko na XVII-XVIII w.

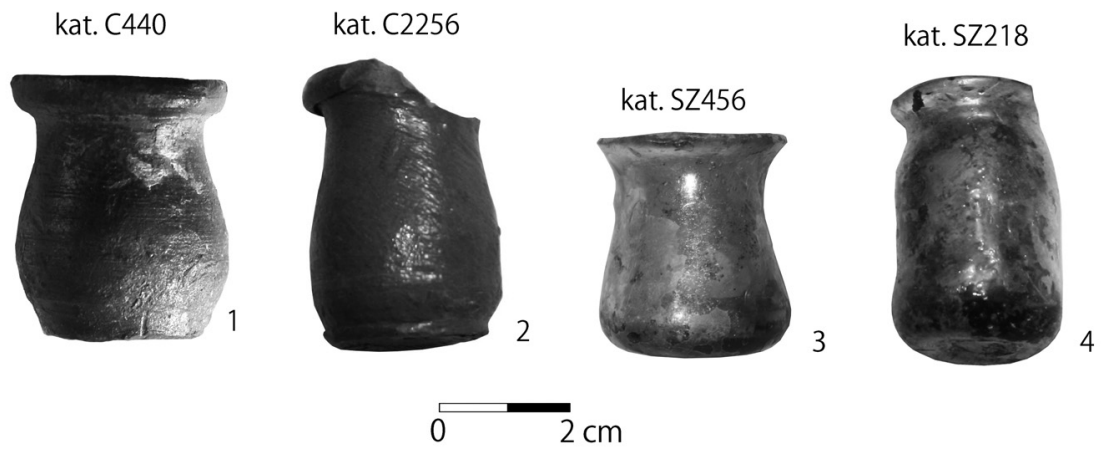

Ryc. 2. Kamionkowe i szklane pojemniki na leki, fot. J. Dąbal, K. Szczepanowska.

Drugą kategorię wielkościową w analizowanym zbiorze reprezentują cztery pojemniki wykonane $\mathrm{z}$ gliny ${ }^{28}$ i $\mathrm{szkła}^{29}$. Wśród wyrobów

${ }^{25}$ Około $3 \mathrm{~mm}$.

${ }^{26}$ Około 5-6 mm

${ }^{27}$ Brak bezpośrednich analogii do opisanych egzemplarzy. Datowanie wykonano w oparciu o cechy technologiczne i diagnostyczne cechy typologiczne (sposób ukształtowania wylewu, dna).

${ }^{28}$ Egzemplarze z badań przy ul. Stara Stocznia/Wałowa 56, nr kat. C2280; wymiary: średnica dna - $35 \mathrm{~mm}$, wysokość - $55 \mathrm{~mm}$, średnica wylewu - $42 \mathrm{~mm}$, maksymalna objętość $47 \mathrm{ml}$, optymalna objętość produktu w pojemniku $30 \mathrm{ml}, 1$ uncja, 30 gramów; nr kat. C902; wymiary: średnica dna - $40 \mathrm{~mm}$, wysokość - $76 \mathrm{~mm}$, średnica wylewu - $56 \mathrm{~mm}$, maksymalna objętość $95 \mathrm{ml}$, optymalna objętość produktu w pojemniku $90 \mathrm{ml}, 3$ uncje, 90 gramów.

${ }_{29}^{29}$ Oba egzemplarze z badań przy ul. Stara Stocznia/Wałowa 56, nr kat. SZ615, wymiary: średnica dna - $37 \mathrm{~mm}$, wysokość - $50 \mathrm{~mm}$, średnica wylewu-34 mm, maksymalna objętość $53 \mathrm{ml}$, optymalna objętość produktu w pojemniku $45 \mathrm{ml}, 1$ i 1/2 uncji, 45 gramów; nr kat. SZ456; wymiary: średnica dna - $38 \mathrm{~mm}$, wysokość - $52 \mathrm{~mm}$, średnica 
ceramicznych wyróżniono pojemnik wykonany na kole, o cylindrycznym ceglastym korpusie i szeroko rozchylonym wylewie (ryc. 3:1). Słoiczek szkliwiony jest wewnętrznie polewą barwioną ceglastobrązowo. Na zewnętrznej powierzchni widoczne są drobne ślady szkliwa. Sposób uformowania naczynia oraz jego cechy technologiczne pozwalają datować egzemplarz na koniec XVI do początku XVII w. ${ }^{30}$ Egzemplarz pochodzi prawdopodobnie $\mathrm{z}$ niderlandzkich warsztatów ceramicznych $^{31}$. Pojemnik pozyskano z warstwy zasypiskowej kanału Młyńskiego datowanej do pierwszej połowy XVII w. Z gliny wypalanej na kolor ciemnoszary wykonany został drugi kamionkowy pojemnik (ryc. 3:2). Powierzchnia zewnętrzna słoika pokryta została polewą żelazistą barwiącą się ciemnobrązowo. Egzemplarz posiada beczułkowaty korpus z wyraźnymi śladami toczenia w formie delikatnych dookolnych pierścieni. Wylew słoika jest lekko rozchylony i ma delikatnie zaokrągloną krawędź. Chronologię naczynia określono na drugą połowę XVII w. do początku XVIII w. ${ }^{32}$

Wśród pojemników średniej wielkości wyróżniono też dwa egzemplarze wykonane ze szkła. Pierwszy wytworzono techniką dmuchania ze szkła barwionego jasnozielonego. Szczegółowe obserwacje masy szklanej utrudnił stan zachowania analizowanego egzemplarza, powierzchnia słoika jest rozwarstwiona, skorodowana. Pojemnik posiada stożkowato wyniesione dno, lekko zwężający się w górnej partii korpus i szeroko rozchylony wylew (ryc. 3:3). Słoik datowano na koniec XVII do pierwszej ćwierci XVIII w. ${ }^{33}$ Naczynie pozyskano z warstwy akumulacyjnej kanału datowanej ogólnie na wiek XVIII. Kolejny szklany egzemplarz wykonano ze szkła bezbarwnego techniką dmuchania (ryc. 3:4). Powierzchnie pojemnika są skorodowane. Słoik posiada delikatnie wyniesione dno ${ }^{34}$, cylindryczny korpus i wylew o krawędzi rozchylonej prostopadle do ścianek naczynia. Egzemplarz datowano na drugą połowę XVIII w. ${ }^{35}$

wylewu - $40 \mathrm{~mm}$, maksymalna objętość $58 \mathrm{ml}$, optymalna objętość produktu w pojemniku 45 ml, 1 i 1/2 uncji, 45 gramów.

${ }^{30}$ E.M.Ch. F. Klijn, dz. cyt., s. 260.

${ }^{31}$ Tamże.

32 A. König, dz. cyt., s. 144-145.

${ }^{33}$ H. Schäfer, G. Schindler, Alles was wir sehen das mus fallen und vergehen Anno 1699. Funde aus dem Umfeld des Barbierchirurgen Dionysius Behrens aus der Mühlenstraße 11 in Greifswald, „Archäologische Berichte aus Mecklenburg-Vorpommern” 2008, Bd. 15, s. 206-207.

34 2-3 mm.

${ }_{35}$ M. Maciaszek, Zabytki szklane, [w:] Wrak statku General Carleton, 1785, W. Ossowski (red.), Gdańsk 2008, s. 239-240. 


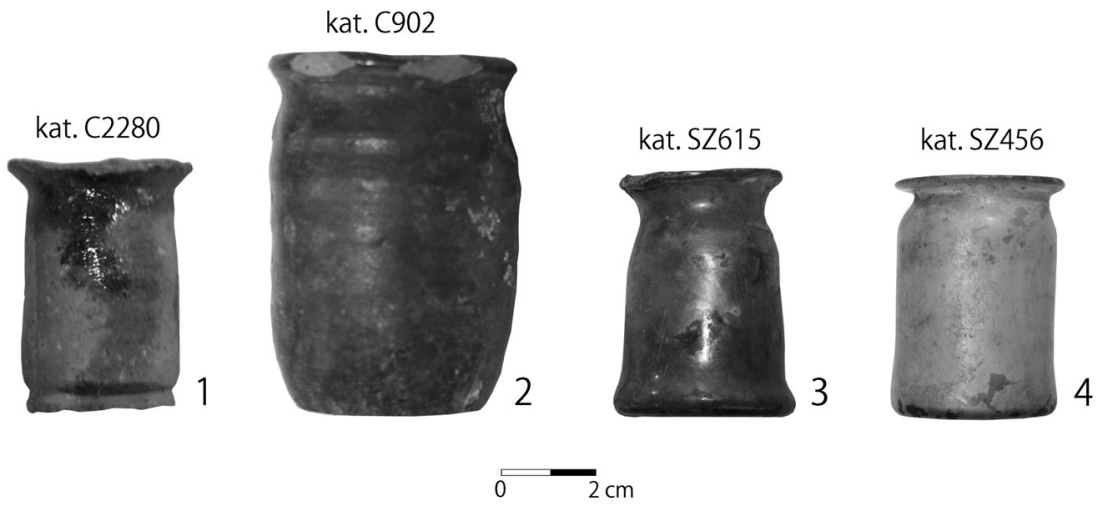

Ryc. 3. Ceramiczne i szklane pojemniki na leki, fot. J. Dąbal, K. Szczepanowska.

Do trzeciej kategorii wielkościowej pojemników zaliczono trzy wyroby ceramiczne o większej objętości ${ }^{36}$. Wszystkie wyroby zachowały się w niepełnej formie, w części den i pod względem technologicznym reprezentują grupę wyrobów majolikowych. Naczynia wykonano na kole techniką toczenia. Dwa egzemplarze posiadają lekko wyniesione dno, trzeci osadzony jest płasko. Dwa egzemplarze wytworzone zostały z glin barwiących się po wypaleniu na kolor beżowy, jedno naczynie wykonano z glin barwiących się po wypaleniu na kolor różowy. Powierzchnie wszystkich pojemników pokryte są obustronnie szkliwem cynowo-ołowiowym i dekorowane polichromowanym lub niebieskim malowaniem podszkliwnym. Pierwszy pojemnik ${ }^{37} \mathrm{w}$ centralnej partii malowany jest niebieskimi, spiralnymi przeplatanymi liniami tworzącymi formę nieregularnych ogniw (ryc. 4:1). Analogicznie zdobione egzemplarze pochodzą z wytwórni niderlandzkich i datowane są na drugą połowę XVI w. ${ }^{38}$ Kolejny pojemnik ${ }^{39} \mathrm{w}$ centralnej partii

36 Wszystkie egzemplarze pozyskano podczas badań na stanowisku 3 Maja 9; nr kat. 470, wymiary: średnica dna - $71 \mathrm{~mm}$, zachowana wysokość - $55 \mathrm{~mm}$ (szacowana wysokość w oparciu o analogie $110 \mathrm{~mm}$ ), maksymalna szacowana objętość $424 \mathrm{ml}$, optymalna objętość produktu w pojemniku $360 \mathrm{ml}, 12$ uncji = 1 funt, 360 gramów; nr kat. 471, wymiary: średnica dna - $88 \mathrm{~mm}$, zachowana wysokość - $78 \mathrm{~mm}$ (szacowana wysokość w oparciu o analogie $125 \mathrm{~mm}$ ), maksymalna szacowana objętość $760 \mathrm{ml}$, optymalna objętość produktu w pojemniku $720 \mathrm{ml}, 24$ uncje = 2 funt, 720 gramów; nr kat. 480, wymiary: średnica dna - $100 \mathrm{~mm}$, zachowana wysokość - $74 \mathrm{~mm}$ (szacowana wysokość w oparciu o analogie $160 \mathrm{~mm}$ ), maksymalna szacowana objętość $1256 \mathrm{ml}$, optymalna objętość produktu w pojemniku $1080 \mathrm{ml}, 36$ uncji = 1 miarka, 1080 gramów.

${ }^{37} \mathrm{Nr}$ kat. 470.

38 Amserdam Ceramics..., dz. cyt., s. 199.

$39 \mathrm{Nr}$ kat. 471. 
dekorowany jest motywami roślinnymi skomponowanymi w trójkątne pola i dominujące kompozycyjnie wypełnienia między nimi (ryc. 4:2). Zdobienia wykonano w kolorach niebieskim, fioletowym i żółtym. $\mathrm{W}$ dnie naczynia znajduje się wtórnie wykonany otwór, który świadczy o innym użytkowaniu pojemnika ${ }^{40}$, prawdopodobnie jako doniczki. Podobnie dekorowane naczynie pozyskano w Delft w Niderlandach i datowano na drugą połowę XVI w. ${ }^{41}$ Trzeci egzemplarz malowano motywami geometrycznymi w trójkątne pola (ryc. 4:3). Dekorację wykonano w kolorach fioletowym i niebieskim. Analogiczne egzemplarze pochodzą z badań archeologicznych w Amsterdamie i datowane są na pierwszą ćwierć XVII w. ${ }^{42}$
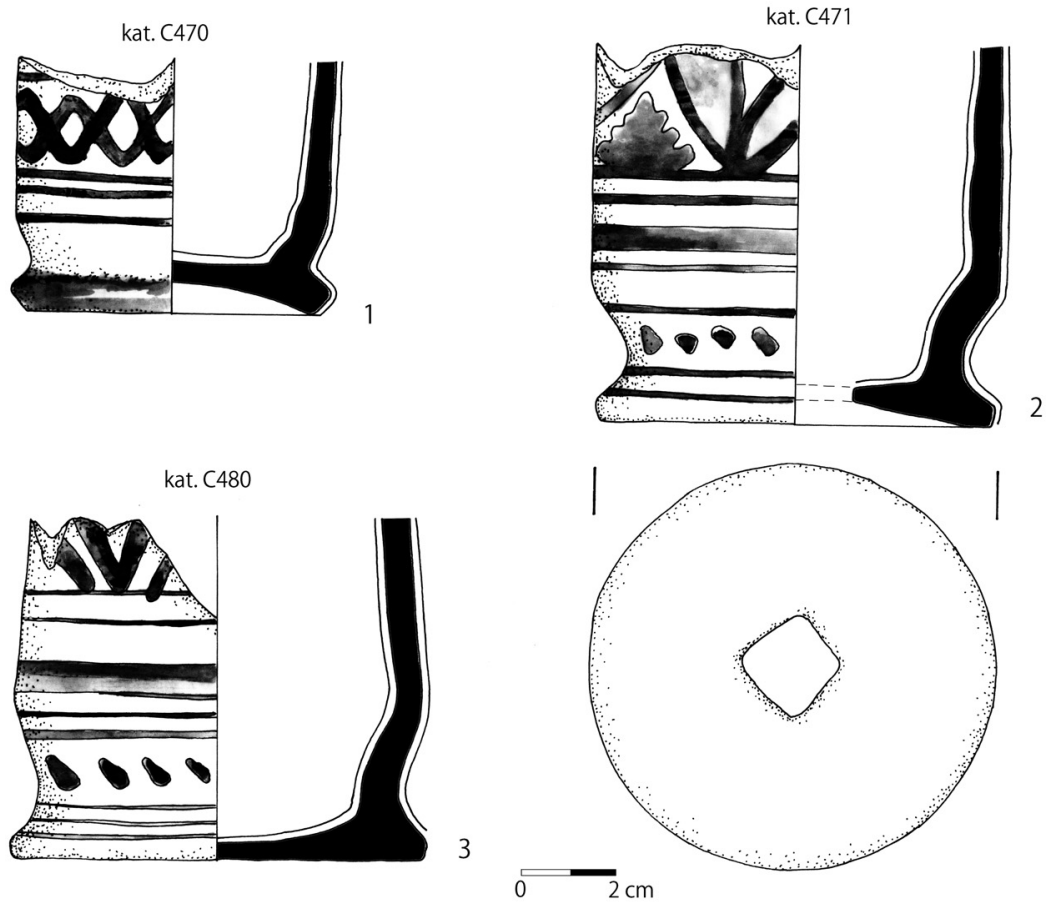

Ryc. 4. Majolikowe pojemniki na leki, rys. A. Dmitruczuk.

${ }^{40}$ Prawdopodobnie po uszkodzeniu.

${ }^{41}$ H.J.E. van Beuningen, J. Hurst, D. Neal, dz. cyt., s. 123-124.

${ }^{42}$ Amserdam Ceramics..., dz. cyt., s. 199. 


\section{Wytwarzanie i skład maści}

Problematyka związana z maściami wykorzystywanymi w epoce nowożytnej jest przedmiotem licznych publikacji. Wymienia się je w oficjalnych farmakopeach ${ }^{43}$, taksach lekarskich ${ }^{44}$ oraz podręcznikach kierowanych do przyszłych adeptów sztuki aptekarskiej ${ }^{45}$. Sa także obecne w słownikach farmaceutycznych ${ }^{46}$, receptach oraz inwentarzach poszczególnych aptek ${ }^{47}$. Zajmującym źródłem są tu również instrukcje przeciwdżumowe ${ }^{48}$, poradniki medyczne, herbarze oraz szeroko pojęta memuarystyka ${ }^{49}$. W niemal każdej z tych kategorii źródeł znajdziemy informacje dotyczące wytwarzania i składu maści. Brakuje tam natomiast dokładniejszych wzmianek dotyczących pojemników do ich przechowywania i sprzedaży ${ }^{50}$.

${ }^{43}$ Najstarszą tego typu farmakopeą jest rękopiśmienna farmakopea gdańska, która znajduje się w zbiorach biblioteki Polskiej Akademii Nauk w Gdańsku. Zob. J. Scheffler, J. Schmidt, Dispensatorium Gedanense continents omnia materialia et medicamenta tam Galenica, quam chymica, quae in officinis Gedanensibus prostant, [Gedani] 1665. $4^{\circ}$ [2 in $\mathrm{ms}$ 953].

${ }^{44} \mathrm{~W}$ dwujęzycznej gdańskiej taksie na leki z roku 1668 (Designatio et valor omnium materialium et medicamentorum tam simplicium quam compositorum, quae in officinis Gedanensibus reperiuntur et venduntur), powstałej na zlecenie Rady Miejskiej, znajdują się nie tylko nazwy i ceny surowców leczniczych i lekarstw, ale także opakowań, w których powinny być one przechowywane. A. Drygas, Aptekarstwo gdańskie 1399-1939, Gdańsk 1983, s. 120-128.

45 Takim dziełem jest podręcznik gdańskiego aptekarza Johannesa Placotomusa wydany w roku 1560 (Pharmacopoea in compendium redacta). W. Roeske, Polskie apteki, Wrocław 1991, s. 90-91; A. Drygas, Jan Placotomus (1514-1577), „Gazeta Farmaceutyczna" 1994, nr 1, s. 45.

${ }^{46}$ Szczególnie cennym w tym względzie jest słownik toruńskiego aptekarza Pawła Guldeniusza. Zob.: Paulus Guldenius, Onomasticum trilingve Latino-Germano-Polonicum rerum et verborum ad officinam pharmaceuticam spectantium..., Regimonti Palaeopoli $1641.4^{\circ}$.

47 S. Proń, Museaum Poloniae pharmaceuticum seu artis pharmaceuticae experimentalis spectrum. Rzecz o muzealnictwie historycznym aptekarstwa w Polsce, Warszawa 1967, s. 265-280.

48 K. Pękacka-Falkowska, Profilaktyka przeciwdżumowa $w$ nowożytnym Toruniu na przykładzie działań administracyjnych i leczenia, Toruń 2009.

${ }^{49}$ Zob. I. Arabas, Apteczki domowe w polskich dworach szlacheckich, Warszawa 2006; J. Węglorz, Zdrowie, choroba i lecznictwo w społeczeństwie Rzeczpospolitej XVI-XVIII wieku, Toruń 2015; J. Szostak, Vademecum lecznictwa domowego z roku 1563, Brzezia Łąka 2016; Apteczka domowa czyli lamus ingrediencyi wszelakich pełen ku zdrowia obronie stużacych, Warszawa 2011; J. Walker, How to Cure the Plague \& Other Curious Remedies, bmw 2013; N. Culpeper, The Tudor Remedy Book. Curious cures for common complaints, bmw. 1996; A. Stobard, Hausehold medicine in seventeenth-century England, bmw 2016; H. Stafski, Aus alten Apotheken, „Bibliothek des Germanischen National-Muzeum zur Deutschen Kunst- und Kulturgeschichte”, L. Grote (red.), Bd. 1, München 1956, s. $28-47$.

${ }^{50}$ Takich informacji brakuje również w pośmiertnych inwentarzach mienia balwierzy, łaziebników, lekarzy, aptekarzy i chirurgów, gdzie ewentualnie wskazuje się tyl- 
Maści najczęściej były preparatami złożonymi (Compositae) z kilku różnych surowców pochodzących ze świata roślin (Vegetabilia), zwierząt (Animalia) lub też minerałów (Mineralia). Z czasem coraz częściej do produkcji maści używano także preparatów chemicznych (Chymica). Przygotowany w ten sposób środek stosowano zewnętrznie do nacierania ciała w przypadku wielu dolegliwości skórnych ${ }^{51}$, chorób wenerycznych ${ }^{52}$, a także epilepsji ${ }^{53}$. Bazę do przygotowania maści stanowiły tłuszcze - zarówno roślinne, jak i zwierzęce ${ }^{54}$. Wiele składników potrzebnych do przygotowania maści było dostępnych $\mathrm{w}$ domowych spiżarniach, droższe natomiast sprowadzano.

W zależności od rodzaju maści można mówić o ich szerokim bądź wąskim działaniu ${ }^{55}$. Nazwy maści najczęściej nawiązywały do ich właściwości, miejsca na ciele, na które miano stosować preparat lub miejsca pochodzenia. Gdańska farmakopea z 1665 r. notuje 40 maści $^{56}$. Zamieszczone $\mathrm{w}$ farmakopei maści sprzedawano w ilości jednego łuta (Von allerley Salben/welche nach dem Loth verschrieben und verkauffet werden), który zgodnie $\mathrm{z}$ norymberskim systemem wagowym odpowiadał połowie uncji, czyli 15 gramom $^{57}$.

Wśród wielu wymienionych tam maści znajdują się te o działaniu chłodzącym, rozgrzewającym czy też łagodzącym. W skład znacznej liczby maści wchodziły przede wszystkim surowce roślinne, w tym liście, korzenie, nasiona, kory, kwiaty, jak również żywice. Tak na przykład stosowana przeciwko szkorfułom, świerzbowi i strupom na

ko ogólnie na różnej wielkości słoiki i puszki do przechowywania maści, moździerze i wagi do odważania składników czynnych maści oraz patele do topienia podłoży (smalcu lub łoju) potrzebnych do zaprawienia maści. Zob.: A. Klonder, Wszystka spuścizna w Bogu spoczywajacego. Majatek ruchomy zwykłych mieszkańców Elblaga i Gdańska w XVII wieku, Warszawa 2000, s. 97-101; K. Pękacka-Falkowska, Inwentarz pośmiertny łaziebnika toruńskiego Johanna Zandera (1709), „KwHKM” 2017, R. LXV, nr 1, s. 79-96; A. Magowska, Życie codzienne poznańskich lekarzy i chirurgów na przełomie XVI i XVII w. w świetle pośmiertnych spisów ruchomości, „KwHKM” 2011, R. LIX, nr 2, s. 139-148.

${ }_{51}$ W. Piotrowski, Medycyna polska epoki kontrreformacji (1600-1764), Jawor 1996, s. 71.

${ }^{52}$ K. Frejlich, „Morbus Gallicus” w Polsce ostatnich Jagiellonów, [w:] Wśród córek Eskulapa. Szkice z dziejów medycyny i higieny w Rzeczpospolitej XVI-XVIII wieku, cz. 2, A. Karpiński (red.), Warszawa 2015, s. 144.

${ }^{53}$ E. Nowosielska, Epilepsja w Rzeczpospolitej w XVII-XVIII w., [w:] Wśród córek Eskulapa..., dz. cyt., s. 244.

${ }^{54}$ A. Stobart, dz. cyt., s. 64, 103.

55 Tamże, s. 43; N. Culpeper, dz. cyt., s. 61.

56 J. Scheffler, J. Schmidt, Dispensatorium Gedanense..., dz. cyt., s. 77-78; szerzej na temat gdańskiej farmakopei zob. A. Drygas, Aptekarstwo Gdańskie..., dz. cyt., s. 113-120.

57 A. Drygas, Aptekarstwo Gdańskie..., dz. cyt., s. 124. 
głowie była maść tytoniowa (Ungu. Nicotinae), dla której za podstawę do przygotowania służyły liście tytoniowe na podłożu smalcu, żywicy i wosku, czy też maść na bazie prawoślazu (Ungu. Althae ae.), w skład której poza kleikiem z korzenia prawoślazu oraz z nasion lnu wchodziła sproszkowana kurkuma oraz smalec i wosk. Gdańskie maści stosowano na wiele różnych części ciała, w tym na przykład oczy (Ungu. Nihili ad oculos), żołądek (Ungu. Stomachalis) czy też śledzionę (Ungu. Splenetici) $)^{58}$.

Poza gdańskimi aptekarzami, wśród których niektórzy słynęli ze sztuki wyrabiania maści ${ }^{59}$, ważną rolę $\mathrm{w}$ procesie ich stosowania i nakładania pełnili chirurdzy miejscy, w których pieczęci obok kleszczy do usuwania kamieni z pęcherza i noża znajdowała się także łopatka do maści ${ }^{60}$. Z pewnością także inne profesje medyczne oraz paramedyczne w Gdańsku wykorzystywały maści w swoim warsztacie pracy ${ }^{61}$.

58 J. Scheffler, J. Schmidt, Dispensatorium Gedanense..., dz. cyt., s. 77-78; por. S. Proń, dz. cyt., s. 265-281.

59 Takim aptekarzem był Antoni Teuchler, który 26 czerwca 1774 r. otrzymał w Poznaniu tytuł królewskiego farmakopoli za swe umiejętności w sztuce wyrabiania maści. A. Drygas, Aptekarstwo Gdańskie..., dz. cyt., s. 65.

${ }^{60}$ S. Sokół, Historia gdańskiego cechu chirurgów (1454-1820), Wrocław-Warszawa 1957, s. 25, 52. Józef Czerniewski z kolei w swym XVIII-wiecznym traktacie o narzędziach cyrulickich wskazuje, że wśród narzędzi, które cyrulik powinien mieć zawsze przy sobie, znajduje się „Szpadel-Spathula. Ten z różnej materyi różnego kształtu i wielkości może być zrobiony. Używany bywa do smarowania plastrów”. Cyt. za: Wybór tekstów źródłowych do dziejów medycyny polskiej, W. Osińska, Z. Podgórska-Klawe (red.), Kraków [b.r.w.], s. 266.

${ }^{61}$ Szerzej na temat przedstawicieli gdańskiego świata medycyny zob. F. Schwarz, Danziger Ärzte im 16.-18. Jahrhundert, „Danziger Familiengesichtliche Beiträge” 1939-1941, H. 4-6, s. 27-36, 21-32, 13-22; J. Kaufman, Über Danziga Sanitatis - und Medizinalwesen im 16. und 17. Jhr., „Mitteilungen des Westpreussischen Gesichtsvereins" 1905, Bd. 4, H. 1-2, s. 4-17, 26-36; J.-H. Kämpfert, Danziger Naturwissenschaftler. Ein Überblick vom ausgehenden Mittelalters bis zum 19. Jahrhundert, [w:] Danzig in acht Jahrhunderten. Beiträge zur Geschichte eines hansischen und preußischen Mittelpunktes. Quellen und Darstellungen zur Geschichte Westpreußen, Bd. 23, B. Jähnig, P. Letkemann (red.), Münster 1985, s. 185-212; tenże, Aspekte der Medizingeschichte im Rahmen der Naturforschenden Gesellschaft, [w:] Deutsch-polnische Begegnung zu Wissenschaft und Kultur Schriftenreihe der Danziger Naturforschenden Gesellschaft, Bd. 2, G.H. Gilbert (red.), Lübeck 1998, s. 36-46; M. Bogucka, Illness und Death in Maritime City. Gdańsk in Seventeenth Century, [w:] Człowiek i świat. Studia $z$ dziejów kultury i mentalności XV-XVIII w., Warszawa 2008, s. 394-410; tejże, Health care and poor relief in Danzig (Gdańsk). The sixteenth-and first half of the seventeenth century, [w:] Health Care und Poor Relief in Protestant Europe 1500-1700, O.P. Grell, A. Cunningham (red.), London 1997, s. 204-219; S. Sokół, Medycyna w Gdańsku w dobie Odrodzenia, Wrocław 1960; tenże, Wędrowni operatorzy w Gdańsku w XVI i XVII w., [Odb. z: Rocznik Gdański 1956/1957 t. 15/16], Gdańsk 1958; B. Siek, A. Szarszewski, Vitae medicorum Gedanensium Ludwiga von Hammena i Valentina Schlieffa, Gdańsk 


\section{Uwagi na temat dystrybucji i użytkowania maści}

Uwagi dotyczące dystrybucji i użytkowania leków w Gdańsku w okresie od końca XVI do XVIII w. mają charakter wstępny. Sformułowano je w oparciu o przekazy pisane, dyspersję i kontekst pozyskania opublikowanych do tej pory źródeł archeologicznych oraz źródła ikonograficzne.

Wydawanie leków wiązało się z działalnością medyków, chirurgów oraz funkcjonowaniem aptek. Z kulturą miejską bogato ilustrowaną w malarstwie wiąże się również działalność znachorów dystrybuujących specyfiki na ulicach ${ }^{62}$. Na obecnym etapie badań zaobserwowano dwie prawidłowości lokalizacji pojemników odkrywanych podczas wykopalisk. Są one odnotowywane w obrębie średniozamożnych i zamożniejszych posesji na historycznym obszarze Głównego Gdańska ${ }^{63}$ (ryc. 1), co wiąże się bezpośrednio z produkcją, przechowywaniem, dystrybucją lub użytkowaniem specyfików przez mieszkańców posesji. Stan badań nie pozwala na obecnym etapie jednoznacznie wskazać, czy opisane opakowania dedykowane były wyłącznie użytkownikom średniozamożnym i zamożnym, a dystrybucję maści wśród uboższych mieszkańców przeprowadzano $\mathrm{w}$ innej formie. Bez wątpienia majolikowe XVI- i XVII-wieczne pojemniki były produktami mniej dostępnymi i bardziej atrakcyjnymi estetycznie. Stan ten potwierdza niewielka liczba analogicznych znalezisk z terenu Gdańska. Opisane wyżej trzy egzemplarze niderlandzkie stanowią najliczniejszy i jedyny zaprezentowany do tej pory zbiór. Również wczesnonowożytne kamionkowe i ceglaste pojemniki są wyrobami importowanymi z terenów Niderlandów i Niemiec do Gdańska, co sugeruje ich mniejszą, ale nie ograniczoną dostępność na rynku w mieście. Do tej pory nie zarejestrowano analogicznych egzemplarzy w publikacjach z Gdańska. Niski stan zaawansowania studiów nad wyrobami szklanymi w Gdań-

2015; Apotheker und Apotheken in Ost- und Westpreußen 1397-1945. Ein Namen-, Ortsund Literaturverzeichnis, „Quellen, Materialien und Sammlungen zur altpreußischen Familienforschung (QMS) Nr. 5", Zusammengestellt v. H. Trunz, Hamburg 1992; M. Łysiak, Doktor medycyny i filozofii Georg Seger (1629-1678), Toruń 2015.

${ }^{62}$ Przykładowo: Jan Victors: Quacksalber auf dem Markt (ok. 1635 r.), Museum of Fine Arts, Budapest; Adriaen Brouwer: The qack doctor (ok. 1625 r.), Staatliche Kunsthalle, Karlsruhe; Jan Steen: The quack (1650-1660), Rijksmuseum, Amsterdam; Cornelis Bega: Alchemist (1663), The J. Paul Getty Museum, Los Angeles.

${ }^{63}$ Przykładem opublikowanych informacji są stanowiska przy ul. Grząskiej 1-4 oraz Szklary 1. Gołembnik zob.: A. Polak, Wstępne wyniki prac prowadzonych w obrębie posesji Szklary 1, 2, 3 oraz Świętojańskiej 10, [w:] Światowit Supplement Series P:Prehistory and Middle Ages, vol. VI, Sezon 2000, A. Gołembnik (red.), Warszawa 2001, s. 161-184; O. Krukowska, Zespót naczyń szklanych..., dz. cyt., s. 247-256. 
sku sprawia, że trudno w tej kwestii jednoznacznie wskazać miejsce produkcji wyrobów ${ }^{64}$. Uwzględniając mało staranną jakość wykonania oraz proporcjonalnie dużą liczebność szklanych pojemników, autorzy stawiają tezę o lokalnej, a nawet miejskiej ich produkcji. W związku $\mathrm{z}$ tym pojemniki szklane zostały zdefiniowane jako szerzej dostępne na rynku.

Drugą wyznaczoną strefą archeologiczną znalezisk naczyń aptecznych są tereny związane ze zwiększoną aktywnością budowlaną w okresie nowożytnym, do których należą obszary budowy i rozbudowy fortyfikacji miejskich, podnoszenie terenu wynikające $z$ niesprzyjających warunków naturalnych oraz funkcjonowanie i zmiany regulacji cieków wodnych ${ }^{65}$ (ryc. 1). W tej sytuacji, w kontekście znalezisk z warstw akumulacyjnych, mamy do czynienia z pojemnikami zdeponowanymi wtórnie i możemy je interpretować jako przedmioty zgubione $^{66}$ lub wyrzucone. Wskazane sytuacje odnoszą się do analizowanych znalezisk ze stanowisk przy ul. 3 Maja 9 i Wałowej/Stara Stocznia 56.

W świetle źródeł historycznych w okresie nowożytnym w Gdańsku maści były obok wielu innych leków preparatem użytkowanym przez wszystkie grupy społeczne ${ }^{67}$. 0 cenie, dostępności, a także sposobie dystrybucji i opakowaniu decydował skład maści. Im bardziej egzotyczne i rzadkie surowce znajdowały się $\mathrm{w}$ przygotowanym preparacie, tym wyższa mogła być jego cena. Maści dystrybuowane były w słoikach. Ich pojemność mogła wskazywać ich bardziej szczegółowe przeznaczenie. Takie rozróżnienie widoczne jest również w przedstawieniach malarskich ukazujących dawkowanie maści z większych pojemników odpowiadających proporcją analizowanych egzemplarzy do niewielkich $1 / 2$ uncjowych słoiczków ${ }^{68}$. W oparciu o analizowane źródła archeologiczne i wyróżnione pojemności opakowań ustalo-

${ }^{64} \mathrm{O}$ hutnictwie Gdańska badacze praktycznie nie wzmiankują, przypisując proweniencję wyrobów szklanych obszarom dzisiejszych Niemiec, Niderlandów czy bardziej odległych Czech.

65 Przykładowe badania własne autorów: pojemniki ceramiczne: stanowisko 30 w Gdańsku, ul. Angielska Grobla/Na Stępce badania 2016, kierownik badań Jakub Prager; pojemniki ceramiczne i szklane: stanowisko 100 w Gdańsku, ul. Szafarnia/Angielska Grobla badania 2007-2008; kierownik badań Bogdan Bobowski.

${ }^{66} \mathrm{~W}$ sytuacji ich obecności w warstwach akumulacyjnych cieków wodnych.

${ }^{67}$ M. Bogucka, Ilness and Death..., dz. cyt., s. 402-410; Z. Kropidłowski, Formy opieki nad ubogimi w Gdańsku od XVI do XVIII wieku, Gdańsk 1992, s. 164-166; E. Kizik, Życie codzienne w Gimnazjum, [w:] Gdańskie Gimnazjum Akademickie. T. 1. Szkice z dziejów, E. Kotarski (red.), Gdańsk 2008, s. 264.

68 Jan Havicksz Steen: The quack (1650-1660), Rijksmuseum, Amsterdam. 
no, że najmniejszą sprzedawaną pojemnością maści była $1 / 2$ uncji ${ }^{69}$. Ustalenia korespondują ze źródłami historycznymi wskazującymi pojemność aplikowanych substancji ${ }^{70}$. Najmniejsze pojemniki stanowiły bez wątpienia produkt detaliczny w Gdańsku. Kolejne wyróżnione objętości opakowań nie są już tak oczywiste. Większe pojemniki ${ }^{71}$ mogły być przeznaczone do przechowywania gotowych preparatów bądź surowców potrzebnych do ich przygotowania.

O użytkownikach leków możemy z kolei wnioskować w oparciu o natężenie występowania pojemników w obrębie miasta. Niewielka liczba zarejestrowanych do tej pory pojemników na medykamenty z okresu od XVI do pierwszej połowy XVII w. świadczyć może o ograniczonym dostępie do medykamentów lub o ograniczonej dystrybucji we wskazanych opakowaniach od XVI do XVII w. ${ }^{72}$ W świetle dotychczasowych publikacji liczniej odnotowywane są dopiero szklane pojemniki datowane od drugiej połowy XVII w. i ich zwiększająca się liczba w wieku XVIII. Prawdopodobnie zjawisko to wiąże się z procesem tzw. medykalizacji w mieście ${ }^{73}$.

\section{Perspektywy badań}

Niewielka liczba publikacji dotycząca szklanych i ceramicznych naczyń na leki z badań archeologicznych w znacznym stopniu utrudnia datowanie nowo odkrytych zabytków tej grupy oraz obserwacje szerszych zjawisk $\mathrm{w}$ kontekście przestrzeni miasta. Z perspektywy studiów nad dystrybucją substancji medycznych w nowożytnym Gdańsku istotna jest poprawna identyfikacja form naczyń oraz rzetelne dane liczbowe i technologiczne prezentowane w publikacjach, umożliwiające porównywanie danych w celu poszerzenia interpretacji. Do pełniejszego wyjaśnienia tych zagadnień niezbędna jest współpraca wielu wzajemnie uzupełniających się dyscyplin naukowych. Studia dotyczące materialnych aspektów historii medycyny w nowożytnym Gdańsku z pewnością wymagają jeszcze pogłębienia. Najnowsza, pra-

$691 / 2$ uncji $=1$ łut.

70 Zob. podrozdział „wytwarzanie i skład maści”.

7112 do 36 uncji.

72 Może się to wiązać także z wykorzystywaniem innych, przykładowo organicznych opakowań funkcjonujących jednoczasowo. Niemniej jednak od momentu pojawienia się pojemników ceramicznych nierejestrowane jest zjawisko popularyzacji tych pojemników.

73 Zob. A. Szarszewski, Lekarzy czujne oczy. Medykalizacja w Gdańsku doby oświecenia, „Klio. Czasopismo poświęcone dziejom Polski i powszechnym” 2010, t. 15, nr 2, s. 59-93. 
wie trzydziestoletnia historia intensywnych badań archeologicznych w mieście dostarczyła do tej pory zaledwie pojedynczych opublikowanych danych na temat pojemników na maści. Po raz pierwszy w polskiej literaturze, $w$ niniejszym artykule zaprezentowano najstarsze ceramiczne pojemniki na maści pochodzące z prac wykopaliskowych w Gdańsku. Podjęto także próbę uporządkowania chronologicznego zarejestrowanych do tej pory form glinianych i szklanych słoików. Przedstawiona perspektywa interpretacji potencjalnej zawartości tych pojemników w kontekście źródeł historycznych jest propozycją mającą na celu poszerzenie możliwości narracji obrazów przeszłości i nakreślenia kierunków precyzyjnych analiz chemicznych czy fizycznych w celu potwierdzenia danych. Prezentacja wymaga jeszcze licznych uzupełnień źródłowych, stanowiąc asumpt do dalszego dyskursu naukowego. Przedstawione wyniki korelacji źródeł historycznych, ikonograficznych i materialnych pozwalają na podjęcie w przyszłości głębszej refleksji odnoszącej się do przeszłości Gdańska.

\section{Summary \\ Ceramic and glass ointment jars from archaeological research in Gdańsk}

The paper presents ceramic and glass containers for medicaments dated from the second half of the 16th to the 18th century, excavated in selected areas of Gdańsk. The authors have attempted to clarify the chronology of these products and their interpretation in the context of historical and iconographic sources. The presented results are preliminary, due to the fact that research on the subject matter is not advanced, and the small size of the analyzed collection are of contributory nature. As the final conclusions aspects of everyday life associated with the production and use of ointments and their packaging and distribution in Gdansk in the postmedieval period were emphasized on the basis of interdisciplinary studies.

Keywords: ointments; glass; ceramics; archaeology; Gdańsk 